University of Nebraska - Lincoln

DigitalCommons@University of Nebraska - Lincoln

\title{
Soil quality improvement under an ecologically based farming system in northwest Missouri
}

\author{
Robert J. Kremer \\ USDA-ARS-Cropping Systems and Water Quality Unit, Bob.Kremer@ars.usda.gov \\ Linda F. Hezel \\ USDA-ARS-Cropping Systems and Water Quality Unit
}

Follow this and additional works at: https://digitalcommons.unl.edu/usdaarsfacpub

Kremer, Robert J. and Hezel, Linda F., "Soil quality improvement under an ecologically based farming system in northwest Missouri" (2012). Publications from USDA-ARS / UNL Faculty. 1481.

https://digitalcommons.unl.edu/usdaarsfacpub/1481

This Article is brought to you for free and open access by the U.S. Department of Agriculture: Agricultural Research Service, Lincoln, Nebraska at DigitalCommons@University of Nebraska - Lincoln. It has been accepted for inclusion in Publications from USDA-ARS / UNL Faculty by an authorized administrator of DigitalCommons@University of Nebraska - Lincoln. 


\title{
Soil quality improvement under an ecologically based farming system in northwest Missouri
}

\author{
Robert J. Kremer ${ }^{1 \star}$ and Linda F. Hezel ${ }^{2}$ \\ ${ }^{1}$ USDA-ARS-Cropping Systems and Water Quality Unit, University of Missouri, Columbia, MO 65211, USA. \\ ${ }^{2}$ Prairie Birthday Farm, Kearney, MO 64060, USA. \\ ${ }^{*}$ Corresponding author: Bob.Kremer@ars.usda.gov
}

Accepted 29 March 2012; First published online 16 May 2012

Research Paper

\begin{abstract}
Ecologically based farming conserves and improves the soil resource and protects environmental quality by using organic or natural resources without the application of synthetic chemicals. Soil quality assessment indicates the ability of management systems to optimize soil productivity and to maintain its structural and biological integrity. Our objective was to evaluate the effect of ecologically based management on biochemical characteristics of soil [soil quality indicators (SQI)] as an assessment of soil quality. The study was conducted on an ecologically based farming enterprise established on gently sloping soils of Sharpsburg silt loam (fine montmorillonitic, mesic Typic Argiudolls) in Clay County, Missouri, which was previously under conventional corn and soybean production. The transition to organic farming began in 1995, which included a primary management strategy to restore soil organic matter consisting of the establishment of native prairie plants and the application of composted vegetative residues and litter from horse and laying hen operations. Soils were collected at $0-10 \mathrm{~cm}$ depths from sites under organic production (orchard and vegetable), managed prairie/pasture and from adjacent unmanaged fields during 2003-2008 for soil quality assessment. Soil organic carbon (SOC) and waterstable soil aggregates were considerably increased by up to 60 and $72 \%$, respectively, in organic production sites compared with tilled cropland by the fifth year of assessment. Organically managed systems and restored prairie sites significantly increased $(P<0.05)$ soil enzyme activities compared with unmanaged grass and tilled cropland. For example, dehydrogenase and glucosaminidase activities increased by 60 and $73 \%$, respectively, under organic vegetables compared with tilled cropland. Soil enzyme activities were significantly correlated with SOC content ( $r$ values up to 0.90 , $P<0.001)$. The results of the soil quality assessment suggest that ecologically based management successfully restored biological activity of silt loam soils previously under intensive conventional agriculture. The system practiced at the study sites illustrates how resources internal to the farm (i.e., composts) can be used to manage soil productivity.
\end{abstract}

Key words: agroecosystems, ecosystem restoration, ecosystem services, microbial activity, organic farming, soil aggregate stability, soil enzymes, soil quality

\section{Introduction}

Ecologically based farming systems, or ecological agriculture, purposely manage biological processes at multiple scales - from the rhizosphere to the soil environment, and from field scale to the watershed level ${ }^{1,2}$. These systems are inherently multifunctional because they provide many different ecosystem services or functions to crop and livestock production; air, soil and water quality maintenance; preservation of biological diversity and promotion of human health ${ }^{3}$. Ecologically based farming systems, similarly described for organic management systems ${ }^{4,5}$, inherently manage the distribution and intensity of ecosystem disturbance through reduced tillage to increase soil microbial diversity, soil organic matter and nutrient cycling; maintain biological diversity; and provide complexity to agricultural systems for strong ecological networks through the establishment of cover crops, strip-cropping, filter strips and 'non-crop' landscapes including grasslands and woodlots. The non-crop landscapes are maintained to provide vital habitats for beneficial organisms that overwinter and prey on weed seeds and support flowering plants in adjacent crop production areas. The integration of these natural landscapes into agricultural production systems can sustain the environment by serving as nutrient sinks to capture 
soluble nutrients and as traps for potential xenobiotic contaminants before these impact aquatic ecosystems ${ }^{1,6}$.

To ensure ecologically based practices are beneficial to soil functioning and environmental quality, soil quality assessment can be used to provide the information needed to evaluate the impact of implementing these management systems ${ }^{7}$. The soil quality concept generally encompasses the basic components of physical, chemical and biological properties of soils within its description as the capacity of a specific soil to function under a natural or managed condition to sustain biological productivity, promote plant and animal productivity, and maintain environmental quality ${ }^{8-10}$. Soil health, viewed within the context of soil quality, considers soil as a vital living system to provide sustainability of the soil quality functions, based primarily on ecological characteristics and associated with biological diversity and ecosystem stability ${ }^{8,9}$. Thus, soil health may be a more appropriate expression for assessment of soil management under ecologically based farming practices as organic management seeks to enhance soil biological activity to achieve improved nutrient cycling, plant growth promotion, disease suppression and resilience to environmental stress ${ }^{6,9}$. However, the assessment of soil health can be accommodated through use of soil quality indicators (SQI). Soil quality assessment involves measurement of multiple soil properties representing chemical, physical and biological characteristics. Selection of SQI is dependent on soil characteristics, environmental influences, land use and management goals, and environmental protection ${ }^{11}$. For ecological agricultural systems, a suite of SQI including aggregate stability, soil organic $\mathrm{C}$ and total $\mathrm{N}$, and enzyme activities reliably detect responses after transition to and establishment of ecologically based management practices $^{12}$. Further, a better understanding of overall microbial activity and $\mathrm{C}$ dynamics in these agroecosystems will contribute to estimates of environmental and economic benefits, and aid policy and management decisions for these systems ${ }^{13}$.

Several studies have examined biological SQI in lowinput and organic farming systems, most of which are compared with similar soils and/or crops under 'conventional management ${ }^{14-17}$. Improved soil quality inferred from increases in soil organic matter for soils under ecological or organic management is widely reported and reflects the integration of perennial grasses, cover cropping in crop rotations and incorporation of organic amendments (crop residues, manures and composts) into soils ${ }^{4}$. High microbial activity indicated by soil enzyme activities and $\mathrm{CO}_{2}$ evolution in organic systems contribute to improved resource utilization and enhanced soil fertility $^{18}$. The concurrent increased microbial density and diversity and biological activity in organically managed soils are largely driven by the increases in soil organic matter. Organic $\mathrm{C}$ is widely considered the most important governing factor in soil quality interrelationships ${ }^{19}$ that are expressed in improved biological activities, plant available nutrients and functional soil structure, including high aggregate stability and low bulk density ${ }^{20,21}$. Little or no information is available on soil quality characteristics of the multiple landscape and production components that are integral to an ecologically based farming system. As ecological agriculture functions through interrelationships among soil-plant-animal-environmental components, soil quality assessment can be a useful tool in describing these interactions. Our objective was to evaluate the effect of ecologically based management on selected biochemical, chemical and physical characteristics of soil (SQI) as an assessment of soil quality during transition to organic production on previously tilled cropland. Our hypothesis was that the soil quality of previously intensively tilled cropland can be improved using ecologically based practices of organic amendments and integration of perennial vegetation. The results were collected during a 6-year study conducted at Prairie Birthday Farm (PBF), an ecologically based farm in northwest Missouri. A previous report described the ecosystem restoration process and the integrated foodproducing enterprise at this farm ${ }^{22}$.

\section{Materials and Methods}

\section{Site description, basic management practices and soil analyses}

PBF is located on the dry-mesic loess/glacial till prairie landscape ${ }^{23}$ in Clay County, Missouri, USA $\left(39^{\circ} 20^{\prime} \mathrm{N}\right.$, $\left.94^{\circ} 24^{\prime} \mathrm{W}\right)$. The deep loess soils on the farm are comprised of Sharpsburg silt loam (fine, montmorillonitic and mesic Typic Argiudolls) situated on the summit and 3-10\% slopes of shoulder landscape positions, which are mapped as an 'eroded soil phase ${ }^{24}$. Previous row-cropped maize (Zea mays) and soybean (Glycine max) likely contributed to erosion, which resulted in shallow topsoil depths of $\leqslant 5 \mathrm{~cm}$ on shoulder to about $20 \mathrm{~cm}$ on summit landscape positions.

A diverse production system including native prairie plants, heirloom fruit trees, vegetables, herbs, pastured heritage chickens and rotation paddock horse pastures was established at PBF in 1993. 'Corral compost' is prepared on-farm from mixtures of horse manure, chicken manure + hydrated lime, mixed hardwood sawdust and shavings; and is mixed/aerated in the barn lot by trampling of the horses (Table 1). Compost is applied at rates of $28 \mathrm{Mgha}^{-1}\left(5.3 \mathrm{Mg} \mathrm{Cha}^{-1}\right)$ around fruit trees in the orchard and $14 \mathrm{Mgha}^{-1}\left(2.6 \mathrm{Mg} \mathrm{Cha}^{-1}\right)$ soil-incorporated in vegetable plots. Other management practice details regarding crop rotation and tillage in vegetable sites pest management, pruning and harvest schedules for blueberry, table grape and tree fruit; and vegetative composition and burning schedule for the restored prairie are reported in Hezel and $\mathrm{Kremer}^{22}$. The reference sites were assessed only to gauge progress in expected soilquality changes due to the establishment of ecological 
Table 1. Various properties of compost prepared on-site at PBF, 2005-2008.

\begin{tabular}{ll}
\hline Property & Range of values \\
\hline $\mathrm{pH}$ & $7.0-7.6$ \\
$\mathrm{EC}(1: 1$, solid:water suspension) & $5.5-6.0 \mathrm{dS} \mathrm{m}^{-1}$ \\
Total C & $18.65-20.2 \mathrm{~g} \mathrm{~kg}^{-1}$ \\
Total N & $1.25-1.30 \mathrm{~g} \mathrm{~kg}^{-1}$ \\
$\mathrm{C}: \mathrm{N}$ ratio & $14.9-15.5$ \\
Total P & $4.5-5.0 \mathrm{~g} \mathrm{~kg}^{-1}$ \\
Total K & $8.9-10.1 \mathrm{~g} \mathrm{~kg}^{-1}$ \\
Total Ca & $20-23.5 \mathrm{~g} \mathrm{~kg}^{-1}$ \\
Total Mg & $2.5-4.5 \mathrm{~g} \mathrm{~kg}^{-1}$ \\
Total Zn & $130-142 \mathrm{mg} \mathrm{kg}^{-1}$ \\
Total Fe & $6300-6600 \mathrm{mg} \mathrm{kg}^{-1}$ \\
Total Mn & $743-760 \mathrm{mg} \mathrm{kg}^{-1}$ \\
Total Cu & $30-35 \mathrm{mg} \mathrm{kg}^{-1}$ \\
Moisture & $400-500 \mathrm{~g} \mathrm{~kg}^{-1}$ \\
Dehydrogenase activity & $50-127 \mu \mathrm{TPF} \mathrm{g}^{-1}$ \\
Glucosaminidase activity & $490-550 \mu \mathrm{g} \mathrm{PNP} \mathrm{g}^{-1}$ \\
FDA hydrolase activity & $600-750 \mu \mathrm{g} \mathrm{fluorescein} \mathrm{g}^{-1}$ \\
\hline
\end{tabular}

Random samples collected at least once annually during a 4-year period from available compost applied during a single year; thus data represent different batches prepared in different years rather than composite samples.

FDA, fluorescein diacetate.

management, differing primarily in tillage and organic amendment, on a similar landscape. These sites included adjacent unmanaged grass and hay fields (no inputs, forage harvested at least once annually) and a conventionally managed field rotationally cropped for corn and soybean (glyphosate-resistant varieties managed according to standard fertilizer and pesticide recommendations ${ }^{25}$ ) initially assessed in 2005 and 2007, respectively. Soil chemical properties were variable with $\mathrm{pH}$ ranging from 5.7 to 6.9 , soil organic matter content of topsoil from 3.0 to $6.0 \%$, and phosphorus and potassium contents of 23-345 and 130-760 $\mathrm{kg} \mathrm{ha}^{-1}$, respectively. Total annual precipitation averages $920 \mathrm{~mm}$; temperatures range from -14 to $30^{\circ} \mathrm{C}$, with an average summer temperature of $25^{\circ} \mathrm{C}^{23}$.

Annual soil sample collection for soil quality analyses was conducted between June 15 and July 15 during 2003-2008. Soils were collected to a $10-\mathrm{cm}$ depth using a stainless steel probe that removed a $3.8 \mathrm{~cm}$ diameter core. The soil samples were collected following transects established across the landscape within the restored prairie and managed pasture. For the smaller areas on which vegetable plot, tree fruit orchard (TFO), blueberry and table grape production were situated, soils were collected from three randomly assigned points within each production area. The reference sites within the same landscape and soil association were also sampled and included: (1) an adjacent fallow, non-grazed grass field (sampled 2005-2008); and (2) an adjacent field under long-term traditional cultivation for $\geqslant 17$ years (sampled in 2007 and 2008 only). Two soil cores were collected at three random points along each transect (restored prairie, managed pasture and reference sites) or within production areas and composited for each point. Soils were transported in a cooler at ambient soil temperature to the laboratory, passed through a 7-mm mesh sieve and stored in plastic bags at $4^{\circ} \mathrm{C}$ prior to analyses.

Total nitrogen (TN) and soil organic carbon (SOC) contents of each soil sample were determined, beginning in 2003 , by dry combustion at $900^{\circ} \mathrm{C}$ using a LECO TruSpec C/N analyzer (LECO Corp., St. Joseph, MI) ${ }^{26}$. Water-stable aggregates (WSA) were determined on 10-g air-dried soil samples using the wet-sieving method ${ }^{27,28}$. Soil samples were spread on a $250-\mu \mathrm{m}$ sieve, placed on the wet-sieving apparatus and subjected to periodic immersion in water (30 vertical strokes per minute for $10 \mathrm{~min}$ ). Soil particles that passed through the sieve were considered the fraction that was unstable in water. Soil remaining on the sieve was dried at $105^{\circ} \mathrm{C}$, weighed and dispersed with $50 \mathrm{ml}$ of $0.5 \%$ sodium hexa-metaphosphate to separate water-stable soil fractions from coarse particles. Coarse particles were collected, dried and weighed. The proportion of WSA was calculated as a percentage of the weight of the stable fraction of the total soil weight.

Soil microbial activity was represented as the activity determined for selected soil enzymes. Dehydrogenase activity based on reduction of the substrate triphenyltetrazolium chloride (TTC) was used to estimate respiratory activity for viable soil micro-organisms ${ }^{29}$. Soil $(6 \mathrm{~g}$, fresh weight) was incubated in $1.0 \mathrm{ml}$ of $3 \%$ TTC and $3.0 \mathrm{ml}$ of $0.2 \mathrm{M} \mathrm{CaCO}_{3}$ for $24 \mathrm{~h}$ at $37^{\circ} \mathrm{C}$. Reactions were terminated by adding $50 \mathrm{ml}$ of methanol and extracted $30 \mathrm{~min}$ on a rotary shaker. Reaction mixtures were filtered, the concentration of the product, 2,3,4-triphenyl-tetrazolium formazan (TPF) was determined spectrophotometrically at $485 \mathrm{~nm}$, and the enzyme activity expressed as $\mu \mathrm{g}$ TPF released $\mathrm{g}^{-1}$ dry soil $\mathrm{h}^{-1}$.

$\beta$-Glucosaminidase activity, representative of nitrogen mineralization, was determined by incubating 1-g soil samples with $p$-nitrophenyl- $N$-acetyl- $\beta$-D-glucosaminide substrate for $1 \mathrm{~h}$ at $37^{\circ} \mathrm{C}^{30}$. After incubation, reaction mixtures were filtered and the concentration of the product, with $p$-nitrophenol (PNP), was determined spectrophotometrically at $405 \mathrm{~nm}$ and the enzyme activity expressed as $\mu$ g PNP released $\mathrm{g}^{-1}$ dry soil $\mathrm{h}^{-1}$.

Fluorescein diacetate (FDA) hydrolysis was determined based on the Schnürer and Roswall method ${ }^{31}$ with modifications ${ }^{32}$. FDA is a general substrate and represents the overall activity of microbial enzymes in soil belonging to the broad classes of esterases, lipases and proteases ${ }^{33}$. FDA hydrolytic activity was detected by spectrophotometrically measuring the product of hydrolysis (fluorescein). The assay consisted of suspending $1.0 \mathrm{~g}$ soil in $20 \mathrm{ml}$ of phosphate buffer ( $\mathrm{pH} 7.6$ ), shaking for $15 \mathrm{~min}$, and adding $100 \mu \mathrm{l}$ of FDA $(4.8 \mathrm{mM})$. The assay mixture was placed on a rotary shaker at 100 $\mathrm{rpm}$ and incubated at $30^{\circ} \mathrm{C}$ for $105 \mathrm{~min}$. The assay was terminated by extraction with acetone $(10 \mathrm{ml})$ followed by filtration through filter paper (Whatman No. 2). 
Absorbance of each filtrate was measured at $490 \mathrm{~nm}$ and the total amount of product formed was calculated based on a regression equation generated from standards of known fluorescein concentration; the enzyme activity was expressed as $\mu$ g fluorescein produced $g^{-1}$ dry soil $\mathrm{h}^{-1}$.

\section{Experimental design and statistical analyses}

As the study was an on-farm experiment, blocks for sampling were established within each production system. Data were analyzed assuming a completely randomized design with eight production systems and six sample years with three replications (blocks). Analysis of variance was conducted to test differences between production systems and year of sampling and to test for homogeneity among SQI parameters. Fisher's protected least significant difference (LSD) was calculated to find significant differences for each measured parameter with significance considered at $\alpha=0.05$. Pearson correlation coefficients were calculated for pairs of soil enzyme and other soil properties including SOC and WSA, and regression models were derived to predict soil enzyme activity using the soil property.

\section{Results}

\section{Soil carbon and nitrogen}

Both SOC and TN differed between the production and managed pasture sites compared with the unimproved cool season grass and continuous cropping sites. By the sixth year of assessment (2008), SOC and TN were higher in all production sites by up to 60 and $78 \%$, respectively, compared to unmanaged grass fields, likely due to annual addition of compost and mulch to production sites or horse manure deposition in the managed pasture (Figs. 1 and 2). Accumulation of SOC and TN under restored native prairie was significantly lower compared with other managed sites, reflecting the longer establishment period for warm season grasses and forbs, and the highly degraded initial soil condition ( $\leqslant 2 \mathrm{~cm}$ topsoil) on which the native plantings were established. Soil organic $\mathrm{C}$ increased in the restored prairie by about $10 \%$ compared to the first year of the assessment period; however, the last-measured $\mathrm{C}$ values were still $46 \%$ higher than that found for the continuous crop site. The $\mathrm{C}$ and $\mathrm{N}$ increases also reflected a gradual decrease in soil $\mathrm{C}: \mathrm{N}$ ratios (not shown) within the managed production systems.

\section{Aggregate stability}

The trends for annual increase for WSA (Fig. 3) in the restored prairie and managed pasture suggested that an effective sink developed for stabilizing the increased $\mathrm{C}$ and $\mathrm{N}$ inputs from perennial vegetation as their root systems developed and established within the soil profile. However, inconsistent increases in WSA in soil under

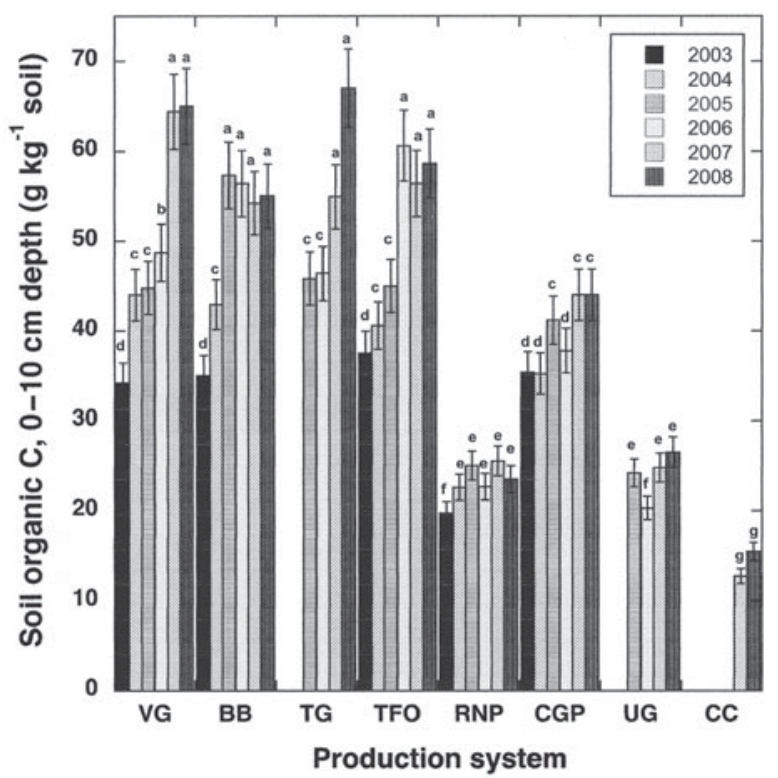

Figure 1. SOC in surface $10 \mathrm{~cm}$ of soils under various management systems in an ecologically based farming system, Clay County, Missouri, 2003-2008. Different letters indicate Fisher's LSD at significance level $P<0.05$; standard error bars for the mean in each year $\times$ production system are also shown. Management systems: VG, vegetable; BB, blueberry; TG, table grapes; TFO, tree fruit orchard; RNP, restored native prairie; CGP, cool season grass pasture; UG, unmanaged grassland; CC, continuously cultivated row crops (maizesoybean rotation).

vegetable and blueberry production (about 25\% WSA for vegetable compared with $58 \%$ for prairie by 2008) may reflect the disturbance effects of tillage used in these intensively managed crops. The gradual increase in WSA under grapes at 5 years after assessment began may be due to the use of various mulches in addition to compost without soil disturbance that contributed to aggregate formation; similarly, increased WSA in TFO soils was a result of the establishment and development of the permanent, native plant vegetation in the alleys, likely a result of continuous root biomass development in the upper soil profile. Low WSA $(<20 \%)$ for the cultivated check soil illustrates the impact of losses of $\mathrm{C}$ and soil structure during prolonged intensive agricultural operations including tillage, minimal crop residue retention and no provision for winter vegetative cover.

\section{Soil enzyme activities}

The predominant trend found in this long-term study was for increasing soil enzyme activities in all managed prairie/pasture and production systems over time compared with the unimproved cool season grass and continuous cropping sites. The highest activities within the production sites were achieved and sustained within 2-3 years after the onset of assessment. For example, 


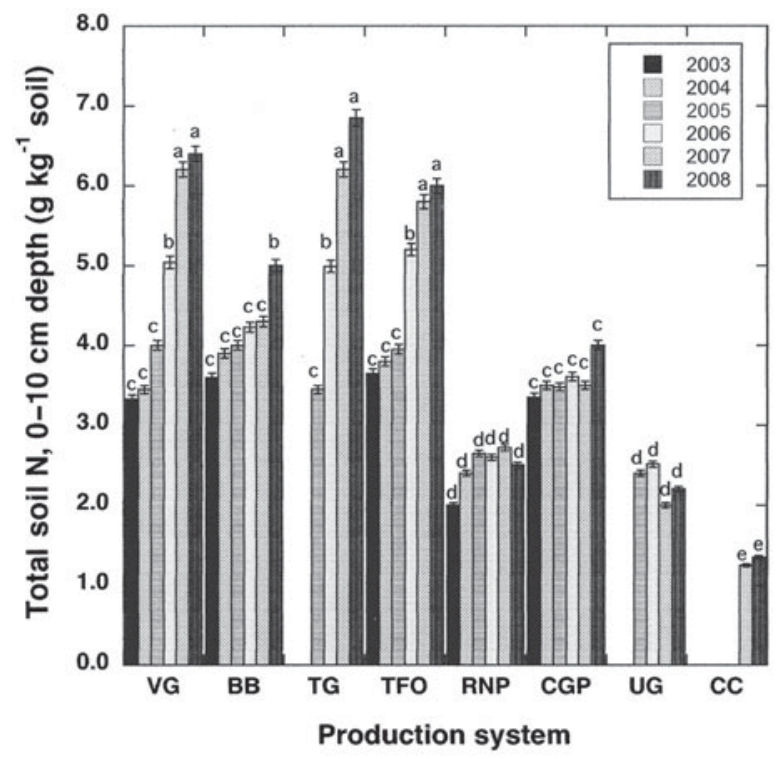

Figure 2. TN in surface $10 \mathrm{~cm}$ of soils under various management systems in an ecologically based farming system, Clay County, Missouri, 2003-2008. Different letters indicate Fisher's LSD at significance level $P<0.05$; standard error bars for the mean in each year $\times$ production system are also shown. Management systems: VG, vegetable; BB, blueberry; TG, table grapes; TFO, tree fruit orchard; RNP, restored native prairie; CGP, cool season grass pasture; UG, unmanaged grassland; CC, continuously cultivated row crops (maizesoybean rotation).

soil dehydrogenase attained high activity levels in the vegetable and grape production sites and in the restored prairie and managed pasture sites by 2006 (Fig. 4). The activity levels in unmanaged grass and continuous cultivated sites were 58 and $78 \%$ lower, respectively, compared with soil dehydrogenase measured in the same year for ecologically managed sites. Trends in $\beta$-glucosaminidase activity were similar to dehydrogenase activity but demonstrated more similarity among all production and managed sites within years (Fig. 5). Also, $\beta$-glucosaminidase activity increased significantly $(P<0.05)$ for all managed sites by the end of the assessment period and was lower in unmanaged grass and continuous cultivated soils at about the same magnitude as for dehydrogenase. Highest soil FDA activities were detected for vegetable, blueberry and table grape production sites; intermediate levels were found for the TFO, managed prairie and pasture sites; and the lowest levels were exhibited in soils from unmanaged grass and continuous cultivated sites (Fig. 6).

Pearson's correlations between enzyme activities and SOC were strong (i.e., $r^{2}=0.62$ for glucosaminidase; 0.91 for FDA hydrolase) across all treatments; however, the enzyme activities were poorly correlated with WSA possibly due to the adverse effects of tillage required to incorporate organic amendments in some production sites.

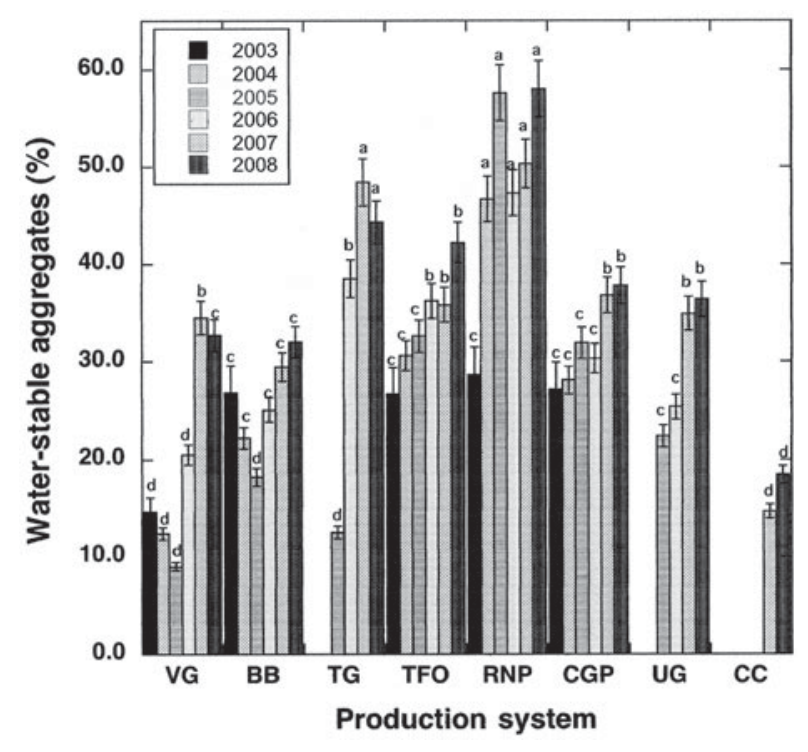

Figure 3. WSA developed in surface $10 \mathrm{~cm}$ of soils under various management systems in an ecologically based farming system, Clay County, Missouri, 2003-2008. Different letters indicate Fisher's LSD at significance level $P<0.05$; standard error bars for the mean in each year $\times$ production system are also shown. Management systems: VG, vegetable; BB, blueberry; TG, table grapes; TFO, tree fruit orchard; RNP, restored native prairie; CGP, cool season grass pasture; $\mathrm{UG}$, unmanaged grassland; $\mathrm{CC}$, continuously cultivated row crops (maize-soybean rotation).

\section{Discussion}

Since transition of the previous conventional farm to an organic system began 14 years ago, all organic management systems followed at PBF have improved the Sharpsburg silt loam in organic-matter content, waterstable aggregation and soil biological activity, including a critical increase in potential $\mathrm{N}$-mineralizing activity. Although water-stable aggregation is somewhat lower at sites receiving composts that are incorporated in soil, the activity and quality of the organic matter developed in place is considerably higher compared with conventional, unmanaged sites within the same landscape. Even though aggregation is relatively high under the unmanaged grasses, the lower microbial activity detected suggests considerably lower soil health resulting from continuous poor management. The differences in enzyme activities between the specific sites are likely due to differences in microbial community structure, substrate characteristics and availability, or soil moisture resulting in spatially variable soil chemical and physical properties. Similar confounding effects on soil microbial function have been reported for alternative soil management compared with crop monocultures ${ }^{34}$. Furthermore, microbial activity in production sites receiving on-farm compost applications was likely stimulated by readily available nutrients contained within the compost (Table 1), analyses of 


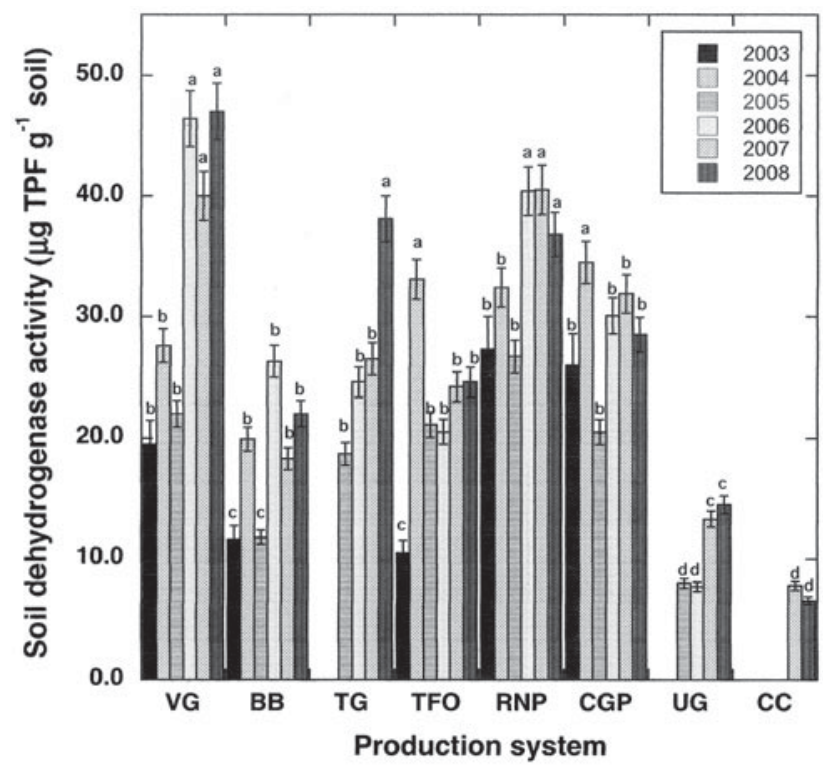

Figure 4. Soil dehydrogenase activity in surface $10 \mathrm{~cm}$ of soils under various management systems in an ecologically based farming system, Clay County, Missouri, 2003-2008. Different letters indicate Fisher's LSD at significance level $P<0.05$; standard error bars for the mean in each year $\times$ production system are also shown. Management systems: VG, vegetable; BB, blueberry; TG, table grapes; TFO, tree fruit orchard; RNP, restored native prairie; CGP, cool season grass pasture; UG, unmanaged grassland; CC, continuously cultivated row crops (maize-soybean rotation). TPF, triphenyl formazam product for quantifying dehydrogenase activity.

which compared very favorably with nutrient-sufficiency levels for composts acceptable as soil amendments ${ }^{35,36}$. We also found very high activities of selected enzymes in the compost (Table 1), which suggested that a highly active beneficial microbial component, or perhaps the enzymes themselves in free or immobilized forms within the compost materials ${ }^{37}$, were added to soil and supplemented indigenous soil microbial diversity and activity $^{38}$.

Annual soil quality assessments since 2003 demonstrated that SOC has consistently increased under organic management compared with conventionally managed soils, leading to improved soil fertility and plant productivity. The prairie site is gradually increasing in SOC, even though the shoulder landscape position was severely eroded leaving very shallow topsoil layers in which SOC could develop and be retained. The high SOC $\left(\approx 40 \mathrm{~g} \mathrm{~kg}^{-1}\right)$ in pasture sites reflects the benefit of integrating livestock in this system. Very high SOC contents in orchard, vegetable, blueberry and grape plots (40$65 \mathrm{~g} \mathrm{~kg}^{-1}$ ) are the result of annual applications of high-quality compost produced on the farm. Increased soil-aggregate stability was associated with long-term organic management, reflecting improved soil aeration, water availability and increased microbial activity. The highest aggregate stability in the prairie site $(50-60 \%$

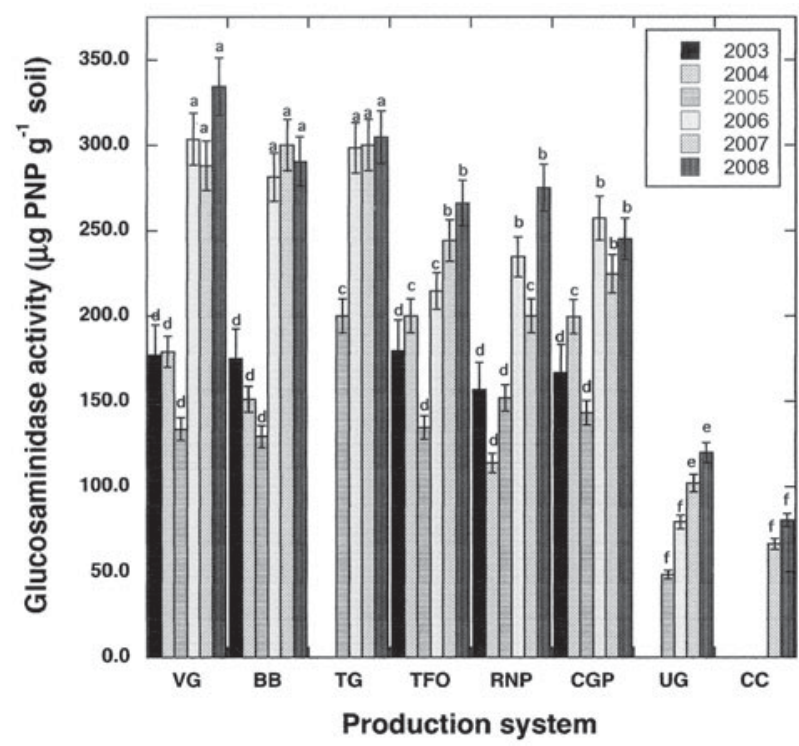

Figure 5. Soil glucosaminidase activity in surface $10 \mathrm{~cm}$ of soils under various management systems in an ecologically based farming system, Clay County, Missouri, 2003-2008. Different letters indicate Fisher's LSD at significance level $P<0.05$; standard error bars for the mean in each year $\times$ production system are also shown. Management systems: VG, vegetable; $\mathrm{BB}$, blueberry; TG, table grapes; TFO, tree fruit orchard; RNP, restored native prairie; CGP, cool season grass pasture; UG, unmanaged grassland; CC, continuously cultivated row crops (maize-soybean rotation). PNP, $p$ nitrophenol product for quantifying glucosaminidase activity.

stable aggregates) exhibits characteristics of soils supporting undisturbed root systems of established perennial grasses. The aggregate stability of pasture and orchard sites was intermediate $(\approx 30 \%)$, demonstrating the contribution of the relatively high SOC as well as the recently established grasses. Aggregate stability under vegetable production only exceeded $20 \%$ during the last 2 years of the survey, yet this site exhibited some of the highest enzyme activities and SOC contents. The contrast in levels of SQI due to tillage required in this production system did not offset the overall increase in soil quality, similar to previous studies in which the incorporation of cow manure and clover green manure with light tillage provided higher soil quality than a conventional no-till system $^{39}$. Unmanaged pasture and hay field sites revealed generally high WSA due to long-term cool-season grass stands and no recent cultivation.

A high WSA percentage indicates excellent soil structure, low erosion potential, good water infiltration and high microbial activity. Previous studies on grassland ecosystems and sustainable agricultural systems have demonstrated the value of high WSA $(40-70 \%)$ in contributing to increased soil organic $\mathrm{C}$ and $\mathrm{N}$ and enhancing soil microbial processes measured as soil enzyme activities $^{40}$. Similarly, stable aggregation, most prevalent in soils with a high density of roots developed from 


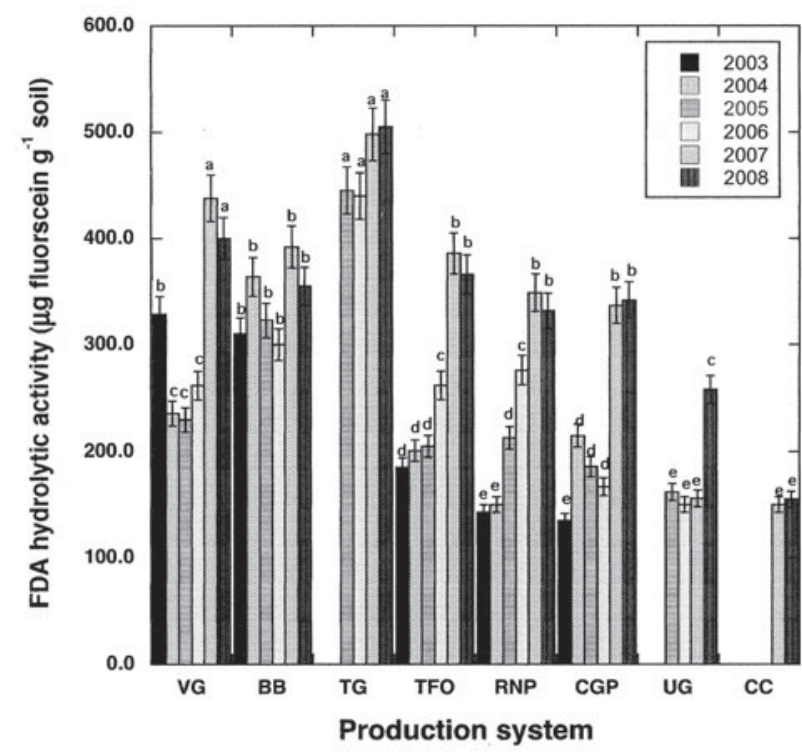

Figure 6. Soil FDA hydrolysis activity in surface $10 \mathrm{~cm}$ of soils under various management systems in an ecologically based farming system, Clay County, Missouri, 2003-2008. Different letters indicate Fisher's LSD at significance level $P<0.05$; standard error bars for the mean in each year $\times$ production system are also shown. Management systems: VG, vegetable; BB, blueberry; TG, table grapes; TFO, tree fruit orchard; RNP, restored native prairie; CGP, cool season grass pasture; $\mathrm{UG}$, unmanaged grassland; $\mathrm{CC}$, continuously cultivated row crops (maize-soybean rotation).

long-term presence of vegetative cover, provided the greatest amounts of organic carbon for aggregate formation ${ }^{41}$. Improvement in WSA therefore suggests that the soil structure and $\mathrm{C}$ were restored on eroded soils through organic inputs associated with the sustainable management practiced at PBF. It is noteworthy that the establishment and maintenance of restored prairie on the severely eroded landscape at PBF increased SOC and WSA two and three times, respectively, compared with the adjacent continuously row-cropped site, confirming the significant impact of perennial grassland on soil quality improvement following conversion from tilled cropland ${ }^{42,43}$.

High potential soil enzyme activities at all organically managed sites demonstrated the impact of systematic amendment of organic materials on the overall improvement of soil health. This coincides with previous conclusions that soil amendments, including animal and green manures, and plant diversity (perennial mixed covers and rotations) are important in maintaining soil microbial activity compared with conventional conservation tillage practices where the repeated applications of inorganic fertilizers suppress production of certain soil enzymes critical in cycling of certain nutrients ${ }^{42}$. Amendment with compost $(\mathrm{pH} \geqslant 7.0$; Table 1) likely aided in maintaining organically managed sites for overall higher microbial activity relative to the unmanaged grass and tilled cropland sites in which soil $\mathrm{pH}$ was $<5.5$. Consistent trends in higher activity of all enzymes assayed in this study validate these as excellent indicators of management-induced changes in soil quality ${ }^{44}$. Microbial dehydrogenase activity (Fig. 4) was significantly higher in soils receiving organic inputs relative to unmanaged or conventionally managed soils. This enzyme, representative of the viable soil microbial community, organic matter decomposition, plant growth promotion and potential plant disease suppression, has frequently been shown to increase under organically managed crops and soils by up to 10 times compared with conventionally managed soils $^{42,45}$.

Nitrogen-mineralizing enzyme activity indicates release of nitrogen (ammonium and nitrate) from organic substances during decomposition by soil micro-organisms. As PBF soils have been amended with organic materials, populations of $\mathrm{N}$-mineralizing micro-organisms were high and very active, thus few differences are seen among organic treatments. However, organic sites provided 5-6 times the $\mathrm{N}$-mineralization potential compared with conventional sites; these extreme differences demonstrate the N-enhancing benefit to soil of organic management. Soil glucosaminidase activity (Fig. 5) indicates mineralization of $\mathrm{N}$ from complex organic substances comprising composts and manures, root tissue and exudates, and dead microbial biomass, eventually becoming available for plant uptake ${ }^{30,46,47}$. Similarly, FDA hydrolytic activity was generally high in soils of the managed pasture/prairie and production sites (Fig. 6). Previous studies also show that FDA hydrolytic activity is an adequate indicator of improved soil quality under managed perennial grass ecosystems ${ }^{48}$ and native forest ${ }^{49}$. The close relationship of SOC and soil microbial activity is consistent with previous studies reporting that while SOC levels indicate the productivity or potential sustainability of a specific agricultural soil, when it is combined with appropriate biological, physical and chemical properties, the impacts of both short- and long-term management on soil quality are evident ${ }^{50}$. It has been further suggested that high levels of organic inputs, as practiced at PBF, contribute to increased microbial abundance and genetic diversity, leading to greater functional diversity and higher metabolic activity (soil enzyme activity) in organic or ecologically managed farming systems ${ }^{45}$.

\section{Conclusions}

The organic process practiced at PBF and sustained over a 16-year period clearly demonstrates how regular amendment with organic materials can improve several aspects of soil health, including increased soil organic matter, improved structure (aggregate stability), and increased microbial activity that contributed to a high potential for mobilizing organic $\mathrm{N}$ for optimum plant growth and 
productivity. The resources internal to the farm (i.e., composts) are used to restore soil quality on organic matter-depleted and eroded soils, resulting from degradation by previous continuous cultivation. Further, perennial systems that include native prairie plants illustrate organic matter 'grown in-place ${ }^{35}$ for improving the properties of soils previously subject to severe erosion and for improving production in perennial horticultural systems (i.e., orchards). Organic growers might readily adapt some or all of the strategies described for the PBF system to improve soil health and crop productivity in other enterprises. It is possible that high soil quality developed under organic management contributes to higher quality fruits and vegetables, as suggested by a recent report on higher quality strawberries produced on high-quality soils under organic management compared with their conventional counterparts ${ }^{51}$. Correlation of soil quality with fruit quality is a current research focus at PBF for subsequent publication.

Soil properties and productivity, represented by improved nutrient cycling, will likely be maintained or improved during the organic transition management that includes scheduled addition of organic amendments consisting of on-farm produced composts and mulches; the restored native prairie will continue to improve soil quality while also providing habitats for beneficial insects and pollinators for the production enterprises on the farm. In addition, the continuous vegetative cover in the prairie, pasture and orchard alleys reduces or eliminates the need for synthetic pest-management chemicals and provides bee-foraging habitats. Finally, the soil quality assessment conducted in this study demonstrated that an ecologically based farming system integrating perennial vegetation with fruit and vegetable sites offers an effective management system for optimizing horticultural crop production while promoting soil conservation. All SQI used were sensitive in detecting soil-property changes as a result of ecologically based management, and allowed interpretation related to the type, magnitude and consequences of altered ecosystem processes. The results of our long-term study have important implications for understanding how ecologically based management practices can enhance soil biological and biochemical processes, to improve the overall soil quality and promote the production of horticultural crops without synthetic chemical inputs, and improve environmental quality.

Acknowledgements. We appreciate the technical support provided by James Ortbals, Jenan Nichols, Nathan Means and Lynn Stanley; and assistance by many student workers over the years of this study (Sarah Lafrenz, Ashley Schlichenmayer, Luke St. Mary, Jennifer N. Smith and John Gardner). Maintenance and transition of the organic farming system was partially supported through a 2002 Sustainable Agriculture Demonstration Award from the Missouri Department of Agriculture, and a 2008 SARE Farmer/Rancher Project grant FNC08-741. Trade names are used for clarity and do not represent endorsement by USDA-ARS or the University of Missouri.

\section{References}

1 Deming, S.R., Johnson, L., Lehnert, D., Mutch, D.R., Probyn, L., Renner, K., Smeenk, J., Thalmann, S., and Worthington, L. 2007. Building a Sustainable Future: Ecologically Based Farming Systems. Extension Bulletin E-2983. Michigan State University, East Lansing, MI.

2 Vandermeer, J.H. 2011. The Ecology of Agroecosystems. Jones \& Bartlett Publishers, Sudbury, MA. p. 387.

3 Daily, G.C., Matson, P.A., and Vitousek, P.M. 1997. Ecosystem services supplied by soil. In G.C. Daily (ed.). Nature's Services: Societal Dependence on Natural Ecosystems. Island Press, Washington, DC. p. 113-132.

4 Stockdale, E.A., Lampkin, N.H., Hovi, M., Keating, R., Lennartsson, E.K.M., Macdonald, D.W., Padel, S., Tattersall, F.H., Wolfe, M.S., and Watson, C.A. 2001. Agronomic and environmental implications of organic farming systems. Advances in Agronomy 70:261-327.

5 Liebig, M.A. and Doran, J.W. 1999. Impact of organic production practices on soil quality indicators. Journal of Environmental Quality 28:1601-1609.

6 Altieri, M.A. 2002. Agroecology: the science of natural resource management for poor farmers in marginal environments. Agriculture, Ecosystems and Environment 93:1-24.

7 Andrews, S.S., Karlen, D.L., and Cambardella, C.A. 2004. The soil management assessment framework: a quantitative soil quality evaluation method. Soil Science Society of America Journal 68:1945-1962.

8 Doran, J.W. and Zeiss, M.R. 2000. Soil health and sustainability: managing the biotic component of soil quality. Applied Soil Ecology 15:3-11.

9 van Bruggen, A.H.C. and Semenov, A.M. 2000. In search of biological indicators for soil health and disease suppression. Applied Soil Ecology 15:13-24.

10 Karlen, D.L., Mausbach, M.J., Doran, J.W., Cline, R.G., Harris, R.F., and Schuman, G.E. 1997. Soil quality: a concept, definition, and framework for evaluation. Soil Science Society of America Journal 61:4-10.

11 Stott, D.E., Andrews, S.S., Liebig, M.A., Wienhold, B.J., and Karlen, D.L. 2010. Evaluation of $\beta$-glucosidase activity as a soil quality indicator for the soil management assessment framework. Soil Science Society of America Journal 74:107-119.

12 Dick, R.P., Breakwell, D.P., and Turco, R.F. 1996. Soil enzyme activities and biodiversity measurements as integrative microbiological indicators. In J.W. Doran and A.J. Jones (eds). Methods of Assessing Soil Quality. Soil Science Society of America Special Publication 49, Soil Science Society of America, Madison, WI. p. 247-271.

13 Delate, K. 2002. Using an agroecological approach to farming systems research. HortTechnology 12:345-354.

14 Drinkwater, L.E., Letourneau, D.K., Worken, F., van Bruggen, A.H.C., and Shennan, C. 1995. Fundamental differences between conventional and organic tomato agroecosystems in California. Ecological Applications 5:10981112.

15 Scow, K.M., Somasco, O., Gunapala, N., Lau, S., Venette, R., Ferris, H., Miller, R., and Shennan, C. 1994. Transition from conventional to low-input agriculture changes soil fertility and biology. California Agriculture 48(5):20-26. 
16 Melero, S., Madejon, E., Herencia, J.F., and Ruiz, J.C. 2008. Effect of implementing organic farming on chemical and biochemical properties of an irrigated loam soil. Agronomy Journal 100:136-144.

17 Wander, M.M., Hedrick, D.S., Kaufman, D., Traina, S.J., Stinner, B.R., Kehrmeyer, S.R., and White, D.C. 1995. The functional significance of the microbial biomass in organic and conventionally managed soils. Plant and Soil 170:87-97.

18 Mäder, P., Fließbach, A., Dubois, D., Gunst, L., Fried, P., and Niggli, U. 2002. Soil fertility and biodiversity in organic farming. Science 296:1694-1697.

19 Arshad, M.A. and Martin, S. 2002. Identifying critical limits for soil quality indicators in agro-ecosystems. Agriculture, Ecosystems and Environment 88:153-160.

20 Acosta-Martinez, V., Zobeck, T.M., Gill, T.E., and Kennedy, A.C. 2003. Enzyme activities and microbial community structure in semiarid agricultural soils. Biology and Fertility of Soils 38:216-227.

21 Pritchett, K., Kennedy, A.C., and Cogger, C.G. 2011. Management effects on soil quality in organic vegetable systems in western Washington. Soil Science Society of America Journal 75:605-615.

22 Hezel, L.F. and Kremer, R.J. 2008. Healing and building soil on Prairie Birthday Farm. Missouri Prairie Journal 29(3):1420.

23 Nelson, P.W. 2005. The Terrestrial Natural Communities of Missouri. Missouri Department of Conservation, Jefferson City, MO. p. 550.

24 Preston, G.D. 1986. Soil Survey of Clay and Ray Counties, Missouri. USDA Soil Conservation Service, US Government Printing Office, Washington, DC.

25 Hoeft, R.G., Nafzinger, E.D., Johnson, R.R., and Aldrich, S.R. 2000. Modern Corn and Soybean Production. MCSP Publications, Champaign, IL.

26 Nelson, D.W. and Sommers, L.E. 1996. Total carbon, organic carbon, and organic matter. In D.L. Sparks (ed.). Methods of Soil Analysis - Part 3: Chemical Methods. Soil Science Society of America, Madison, WI. p. 961-1010.

27 Kemper, W.D. and Rosenau, R.C. 1986. Aggregate stability and size distribution. In A. Klute (ed.). Methods of Soil Analysis - Part 1: Physical Methods. Soil Science Society of America, Madison, WI. p. 425-442.

28 Angers, D.A. and Mehuys, G.R. 1993. Aggregate stability to water. In M.R. Carter (ed.). Soil Sampling and Methods of Analysis. Canadian Society of Soil Science, Lewis Publishers, Boca Raton, FL. p. 651-657.

29 Tabatabai, M.A. 1994. Soil enzymes. In R.W. Weaver (ed.) Methods of Soil Analysis - Part 2: Biological and Biochemical Properties. Soil Science Society of America, Madison, WI. p. 777-823.

30 Parham, J.A. and Deng, S.P. 2000. Detection, quantification and characterization of glucosaminidase activity in soil. Soil Biology and Biochemistry 32:1183-1190.

31 Schnürer, J. and Roswall, T. 1982. Fluorescein diacetate hydrolysis as a measure of total microbial activity in soil and litter. Applied and Environmental Microbiology 43:12561261.

32 Green, V.S., Stott, D.E., and Diack, M. 2006. Assay for fluorescent diacetate hydrolytic activity: optimization for soil samples. Soil Biology and Biochemistry 38:693-701.

33 Dick, R.P. 1997. Soil enzyme activities as integrative indicators of soil health. In C.E. Pankhurst, B.M. Doube, and V.V.S.R. Gupta (eds). Biological Indicators of Soil Health. CAB International, Oxford, UK. p. 121-156.

34 Acosta-Martinez, V., Zobeck, T.M., and Allen, V.G. 2010. Soil microbial communities and function in alternative systems to continuous cotton. Soil Science Society of America Journal 74:1181-1192.

35 Wolf, B. and Snyder, G.H. 2003. Sustainable Soils: The Place of Organic Matter in Sustaining Soils and Their Productivity. Food Products Press, Binghamton, NY. p. 352.

36 Heckman, J.R., Weil, R. and Magdoff, F. 2009. Practical steps to soil fertility for organic agriculture. In C. Francis (ed.). Ecology in Organic Farming Systems. Agronomy Monograph 54, American Society of Agronomy, Madison, WI. p. 139-172.

37 Dick, W.A. and Tabatabai, M.A. 1992. Significant and potential uses of soil enzymes. In F.B. Metting Jr (ed.). Soil Microbial Ecology: Applications in Agricultural and Environmental Management. Marcel-Dekker, New York, p. $95-127$.

38 Acea, M.J. and Carballa, T. 1996. Microbial response to organic amendments in a forest soil. Bioresource Technology 57:193-199.

39 Teasdale, J.R., Coffman, C.B., and Mangum, R.W. 2007. Potential long-term benefits of no-tillage and organic cropping systems for grain production and soil improvement. Agronomy Journal 99:1297-1305.

40 Kremer, R.J. and Li, J. 2003. Developing weed-suppressive soils through improved soil quality management. Soil \& Tillage Research 72:193-202.

41 Jastrow, J.D. and Miller, R.M. 1998. Soil aggregate stability and carbon sequestration: feedbacks through organomineral associations. In R. Lal, J.M. Kimble, R.F. Follett, and B.A. Stewart (eds). Soil Processes and the Carbon Cycle. CRC Press, Boca Raton, FL. p. 207-223.

42 Dick, R.P. 1992. A review: long-term effects of agricultural systems on soil biochemical and microbial parameters. Agriculture, Ecosystems and Environment 40:25-36.

43 Singer, J.W., Franzluebbers, A.F., and Karlen, D.L. 2009. Grass-based farming systems: soil conservation and environmental quality. In W.F. Wedin and S.L. Fales (eds). Grassland: Quietness and Strength for a New American Agriculture. American Society of Agronomy, Madison, WI. p. 121-136.

44 Bandick, A.K. and Dick, R.P. 1999. Field management effects on soil enzyme activities. Soil Biology \& Biochemistry 31:1471-1479.

45 Reeve, J.R., Schadt, C.W., Carpenter-Boggs, L., Sanghoon, K., Zhou, J., and Reganold, J.P. 2010. Effects of soil type and farm management on soil ecological functional genes and microbial activities. ISME Journal 4:1099-1107.

46 Acosta-Martinez, V., Cruz, L., Sotomayor-Ramirez, D., and Perez-Alegria, L. 2007. Enzyme activities as affected by soil properties and land use in a tropical watershed. Applied Soil Eology 35:35-45.

47 Ekenler, M. and Tabatabai, M.A. 2003. Tillage and residue management effects on $\beta$-glucosaminidase activity in soils. Soil Biology and Biochemistry 35:871-874.

48 Udawatta, R.P., Kremer, R.J., Garrett, H.E., and Anderson, S.H. 2009. Soil enzyme activities and physical 
properties in a watershed managed under agroforestry and row-crop systems. Agriculture, Ecosystems and Environment 131:98-104.

49 Fernandesa, M.F., Barretoa, A.C., Mendesb, I.C., and Dick, R.P. 2011. Short-term response of physical and chemical aspects of soil quality of a kaolinitic Kandiudalfs to agricultural practices and its association with microbiological variables. Agriculture, Ecosystems and Environment 142:419-427.
50 Jordan, D., Kremer, R.J., Bergfield, W.A., Kim, K.Y., and Cacnio, V.N. 1995. Evaluation of microbial methods as potential indicators of soil quality in historical agricultural fields. Biology and Fertility of Soils 19:297-302.

51 Reganold, J.P., Andrews, P.K., Reeve, J.R., CarpenterBoggs, L., Schadt, C.W., Alldredge, J.R., Ross, C.F., Davies, N.M., and Zhou, J. 2011. Fruit and soil quality of organic and conventional strawberry agroecosystems. PLoS ONE 5(9):e12346. doi:10.1371/journal.pone.0012346. 